\title{
Socio-pedagogical Features of the Formation of Soft Skills in the Republic of Kazakhstan
}

\author{
Zhuldyz Abaikyzy Amantay ${ }^{1,2 *}$ Dmitry Sergeevich Ermakover, \\ I 71 Al-Farabi Street, Almaty, A15E3B6, Kazakhstan. \\ ${ }^{2}$ Peoples Friendship University of Russia, 6 Miklukho-Maklaya Street, Moscow, 117198, Russia \\ aEmail:ermakov-ds@rudn.ru \\ *Corresponding author. Email: amantay-zh@rudn.ru.
}

\begin{abstract}
Currently, special attention is paid to the formation of future graduates, along with subject (hard skills), also meta-subject competencies (soft skills). As the experience of a number of countries (in particular, developing ones) shows, the large-scale introduction of the components necessary for the development of soft skills into curricula and programs is largely associated with state policy in the field of higher education. This problem is of great importance for the Republic of Kazakhstan. The article presents the results of a survey of 562 students and 59 teachers of Kazakhstan universities about their awareness of soft skills, assessing the level of formation of certain specific skills, the importance of different levels of education for their development, and the effectiveness of relevant pedagogical technologies. It is shown that about half of teachers and students have no idea about soft skills. As the most significant for the formation of soft skills, the senior level of school, secondary vocational and higher education are considered. A deeper development of soft skills is expected than is currently taking place. The most in demand are the formation of their own opinion, judgment and decision-making, communicating, collaborating, coordinating with others, as well as critical thinking, the least - retraining, people management, working under conditions of uncertainty. Among the most effective ways of learning - practices, internships; trainings, games and cases; learning projects. In general, soft skills should be considered as an innovative component of educational content in the Republic of Kazakhstan.
\end{abstract}

Keywords: Soft skills, Student, Teacher, Questionnaire, Republic of Kazakhstan.

\section{INTRODUCTION}

Recently, soft skills have become not only an integral part of the labor market, but are also discussed in various spheres of society. In many contexts, "soft skills" are equated or used as synonyms for such concepts as " employability skills", "people skills", "non-professional skills", in the Organisation for Economic Co-operation and Development (OECD) - "key skills", and lately "skills for social progress", "21st century skills"; in the International Health Organization - "life skills" [1]. Various approaches to the interpretation of the concept under consideration, the compilation of lists of soft skills and their classification are caused by the contextual approaches of researchers.

In many countries of the world, international and national programs are being developed and implemented aimed at introducing soft skills into the curricula of universities and other levels of education. Such steps reflect the requirements of the modern labor market, which is undergoing radical changes under the influence of complex challenges (globalization, greening, digitalization, etc.). The production and environment with a shortened cycle of creating and updating knowledge and technologies has led to significant gaps in the competencies of graduates, who are increasingly facing problems in finding employment, as non-compliant with the requirements for skilled labor [2]. New politica and relevant higher education reforms have begun to be systematically implemented in developed economies, but they are also relevant for developing countries [3]. 


\section{PROBLEM STATEMENT}

At the turn of the XX-XXI centuries, researchers, teachers and specialists from different sectors of the economy began to understand the need to move from teaching specific knowledge to developing competencies. Soft skills are recognized as just such traits (including interaction and motivation, communication, teamwork, commitment and reliability) that relate to personality, behavior, and not to formal subject training.

Organizations such as Partnerships for 21st Century Skills, North Central Regional Educational Laboratory (NCREL), Metri Group, and Educational Testing Service (ETS) have tried to define soft skills and provide a framework for creating new training plans. Specifically, NCREL and Metri Group identified four essential areas: digital literacy, creative thinking, effective communication, and high productivity [4], [5]

In 2019, for the first time in the Republic of Kazakhstan, an international study of the competencies of the adult population was carried out within the framework of the PIAAC (Program for the International Assessment of Adult Competences). On average, reading, math and problem-solving skills in a high-tech environment (which are considered key competencies important for anyone, both in everyday life and in the workplace) were well below the average level of the OECD countries. At the same time, the global trend is when the peak of development falls on 2534 years, and then a decline occurs. However, in Kazakhstan, the skills of the younger generation are sometimes even lower than those of the older generation (55-65 years old). At the same time, among the surveyed citizens aged 25-34, almost $50 \%$ have a higher education, while in the older cohort - only $27 \%$. [6].

The importance of the formation of soft skills in Kazakhstan is noted among the main trends in the transformation of methodology and updating the content already at the level of school education [7]. In the 2018/19 academic year, 20 schools in Almaty introduced a new optional subject for high school students "Soft and hard skills: Fundamentals of Personal and Social Skills Development". An appropriate educational and methodological complex has been prepared, the qualifications of teachers have been improved, an electronic interactive application has been released. The relevance of the problem of "soft" skills is also realized at the level of higher school. In practice, however, there have been only a few isolated initiatives so far. For example, within the framework of the international scholarship program "Bolashak", the courses "Academic English", "Cross-cultural Competencies", as well as "Academic Soft Skills" are studied, which are necessary for successful study abroad. The Academy of Public Administration under the President of the Republic of Kazakhstan hosts seminars "Developing Soft Skills", the Council of Business Women "Atameken conducted a training for students on the development of leadership skills and competitiveness. The School of Orators, the debate center, and the leadership Club operate within the framework of the international clubs Almaty Toastmasters Club, Almaty Debate Center, Writing Marathon. A specialized center for the development of soft skills created. (Almaty) [8].

\section{RESEARCH QUESTIONS}

In the course of implementation of this study, the following questions were studied:

- How familiar are students and teachers of Kazakh universities with the concept of soft skills and how they assess the need for their formation at different levels of education;

- At which degree soft skills are being formed at present and what are the wishes of the subjects of the educational process;

- The usage of which forms and methods of training is most effective in terms of the development of soft skills in the higher education system of the Republic of Kazakhstan.

\section{PURPOSE OF THE STUDY}

The purpose of this work is to substantiate the soft skills model of a graduate of a modern university of the Republic of Kazakhstan in an international context, which can be used in practice to transform the educational process and increase its effectiveness.

\section{RESEARCH METHODS}

The methodology is based on a combination of theoretical and empirical approaches. The analysis of the literature reveals the main directions of modern theoretical research and practical developments in the field of soft skills and their formation in students. Modeling allowed us to get 
idealized ideas about the object under study, to study the essential properties of soft skills as an innovative component of the content of higher education, and to develop an appropriate pedagogical model. Data on the attitude of the subjects of the educational process to the formation of soft skills (both in general and for specific skills), evaluation of the effectiveness of certain methods and forms of training were obtained, as in our previous study [9], through a questionnaire.

The survey was conducted in 2020. It was attended by 562 students of bachelor's, specialist's and master's degrees (including men $41.8 \%$, women $58.2 \%$; age from 17 to 49 years, average value 20.9 years) and 59 teachers (including men $52.5 \%$, women $47.5 \%$; age from 19 to 88 years, average

value 32.7 years; teaching experience from 0 to 52 years, average value 6.9 years) higher educational institutions of the Republic of Kazakhstan (AlFarabi Kazakh National University, L. N. Gumilyov Eurasian National University, K. I. Satbayev Kazakh National Research Technical University, A. Yassawi International KazakhTurkish University, M. Auezov South Kazakhstan University, M. Kh. Dulaty Taraz Regional University etc.).

\section{FINDINGS}

"Table 1" shows the results of the survey with some special questions: "Were you familiar with the concept of soft skills before? If so, where did you find information about it?".

Table 1. Soft skills awareness and information sources $(\%)$

\begin{tabular}{|l|l|l|}
\hline \multicolumn{1}{|c|}{ The response options } & \multicolumn{1}{c|}{ Students } & Teachers \\
\hline Yes & 57.3 & 55.9 \\
\hline No & 42.7 & 44.1 \\
\hline Information sources (\% of "Yes"): & 11,7 & 15,2 \\
\hline from official documents & 43,8 & 30,3 \\
\hline from the administration, management of the University & 48,8 & 39,4 \\
\hline from colleagues (for study / work) & 17,5 & 12,1 \\
\hline in advanced training courses & 21,7 & 27,3 \\
\hline from pedagogical publications & 46,3 & 30,3 \\
\hline from mass media & & \\
\hline
\end{tabular}

The degree of awareness of students (57.3\%) and teachers $(55.9 \%)$ is generally similar. At the same time, the relationship with age (correlation coefficient 0.11 and 0.095 , respectively) and teaching experience (0.0036) is not expressed. The main sources of information for students are fellow students $(48.8 \%)$, the mass media $(46.3 \%)$ and the university administration (43.8\%), and for teachers - work colleagues (39.4\%), mass media (30.3\%) and management $(30.3 \%)$. Attention is drawn to the low activity of advanced training courses (12.1\%), students - familiarity with official documents $(11.7 \%)$.

Answers to the question "How do you assess the need of formation of students' soft skills at various levels and stages of education?" (Difficult to answer - 0 ; no need to -1 ; you need specific to students (upon request) - 2; requires certain categories of students (gifted, non-adaptive, etc.) 3 ; you need all -4 ) are given in "Table 2".
In accordance with the average grades on the above 4-point scale, students and teachers consider the most significant stages of higher, secondary vocational and secondary general education (3.53 and 3.36, 3.23 and 3.20, 3.26 and 3.07, respectively). The specifics of training in preschool educational organizations and primary schools may not be familiar to teachers and University students. According to respondents, the potential for developing soft skills in the system of additional education (both for children and for adults) is insignificant.

To determine the degree of formation of certain specific soft skills in an educational organization at the place of study / work, a list was proposed based on models developed by international experts [10], [11], [12]. "Table 3" presents the estimates obtained for the real and desired state of Affairs (on a 3point scale: not specially formed / not formed - 1; partly - 2; deeply - 3). 
Table 2. Evaluating the need for creating soft skills (\%)

\begin{tabular}{|c|c|c|c|c|c|c|c|c|c|c|}
\hline \multirow{2}{*}{ Levels and stages of education } & \multicolumn{5}{|c|}{ Students } & \multicolumn{5}{|c|}{ Teachers } \\
\hline & 0 & 1 & 2 & 3 & 4 & 0 & 1 & 2 & 3 & 4 \\
\hline elementary general education & 12,9 & 24,6 & 18,1 & 37,5 & 12,9 & 16,9 & 18,6 & 18,6 & 37,3 & 16,9 \\
\hline secondary general education & 6,4 & 13,6 & 18,7 & 59,2 & 6,4 & 10,7 & 10,7 & 17,9 & 55,4 & 10,7 \\
\hline additional education of children & 6,3 & 18,8 & 27,9 & 42,2 & 6,3 & 6,9 & 19,0 & 32,8 & 37,9 & 6,9 \\
\hline vocational secondary education & 5,7 & 11,6 & 20,0 & 59,4 & 5,7 & 5,4 & 10,7 & 21,4 & 57,1 & 5,4 \\
\hline
\end{tabular}

Table 3. Assessment of the degree of formation of soft skills (score)

\begin{tabular}{|c|c|c|c|c|}
\hline Soft skills & \multicolumn{2}{|c|}{ Students } & \multicolumn{2}{|c|}{ Teachers } \\
\hline An adequate perception of criticism is really desirable & 1,91 & 2,65 & 1,78 & 2,63 \\
\hline Negotiation & 1,87 & 2,67 & 2,00 & 2,59 \\
\hline Service orientation & 1,79 & 2,45 & 1,73 & 2,36 \\
\hline Communicating & 2,22 & 2,67 & 2,19 & 2,71 \\
\hline Collaborating & 2,10 & 2,67 & 2,07 & 2,66 \\
\hline Coordinating with others & 1,99 & 2,66 & 1,83 & 2,69 \\
\hline Creativity & 1,96 & 2,49 & 1,95 & 2,47 \\
\hline Retrain & 1,81 & 2,30 & 1,68 & 2,15 \\
\hline Judgment and decision making & 1,93 & 2,70 & 1,97 & 2,69 \\
\hline Risk taking & 1,82 & 2,56 & 1,80 & 2,53 \\
\hline Working under uncertainty & 1,82 & 2,43 & 1,78 & 2,39 \\
\hline Complex problem solving & 2,01 & 2,61 & 1,88 & 2,61 \\
\hline Social responsibility & 1,93 & 2,64 & 1,92 & 2,64 \\
\hline \multirow{2}{*}{ Soft skills } & \multicolumn{2}{|c|}{ Students } & \multicolumn{2}{|c|}{ Teachers } \\
\hline & Really & Desirable & Really & Preferably \\
\hline Emotional intelligence & 1,72 & 2,60 & 1,71 & 2,59 \\
\hline
\end{tabular}

Students and teachers evaluate both the real and desired situation almost equally (average scores are
1.89 and $1.87 ; 2.56$ and 2.63 , respectively). In general, a more intensive development of soft skills 
in the educational process is expected than there is. Positions regarding specific skills are also similar. The most in demand are the formation of their own opinion, judgment and decision making, communicating, collaborating, coordinating with others, associated with the implementation of joint activities with other people, as well as critical thinking, which is generally consistent with the concept of "4C" [11]. Least priority is retraining, people management, working under conditions of uncertainty.

It is known that the formation of soft skills in the educational process is more influenced by the

Table 4. Evaluation of the effectiveness of forms and methods of forming soft skills (\%)

\begin{tabular}{|l|l|l|l|l|l|l|l|l|l|l|l|}
\hline \multirow{2}{*}{ Forms and methods of training } & \multicolumn{9}{|c|}{ Students } & \multicolumn{1}{|c|}{ Teachers } \\
\cline { 2 - 12 } & 1 & 2 & 3 & 4 & 5 & 1 & 2 & 3 & 4 & 5 \\
\hline Contests Olympics & 23,9 & 31,3 & 24,8 & 12,4 & 7,6 & 10,7 & 19,6 & 33,9 & 26,8 & 8,9 \\
\hline Multimedia training & 10,0 & 27,3 & 38,2 & 13,8 & 10,7 & 10,2 & 22,0 & 37,3 & 15,3 & 15,3 \\
\hline Individual (special) discipline & 6,9 & 17,6 & 40,2 & 21,5 & 13,7 & 3,4 & 10,2 & 49,2 & 27,1 & 10,2 \\
\hline Separate tasks in different subjects & 5,4 & 17,9 & 41,8 & 22,8 & 12,2 & 1,7 & 10,2 & 40,7 & 32,2 & 15,3 \\
\hline $\begin{array}{l}\text { Single topics / modules in different } \\
\text { disciplines }\end{array}$ & 2,1 & 20,9 & 39,5 & 24,6 & 12,9 & 1,7 & 18,6 & 39,0 & 23,7 & 16,9 \\
\hline Practices, internships & 3,2 & 9,3 & 21,5 & 36,8 & 29,2 & 0,0 & 3,4 & 20,3 & 42,4 & 33,9 \\
\hline Testing & 17,3 & 29,0 & 23,7 & 19,9 & 10,1 & 16,9 & 32,2 & 16,9 & 27,1 & 6,8 \\
\hline Trainings, games, case studies & 3,6 & 11,3 & 20,9 & 38,6 & 25,7 & 3,4 & 13,6 & 28,8 & 33,9 & 20,3 \\
\hline Learning projects & 7,2 & 13,1 & 25,3 & 32,1 & 22,3 & 1,7 & 17,2 & 34,5 & 27,6 & 19,0 \\
\hline E-learning, virtual learning & 12,4 & 29,4 & 29,0 & 16,3 & 12,9 & 11,9 & 20,3 & 28,8 & 23,7 & 15,3 \\
\hline
\end{tabular}

According to the above 5-point school, the most preference is given by both teachers (4.07) and students (3.80) to practices and internships, followed by trainings, games and cases; learning projects (3.72 and 3.54; 3.45 and 3.49, respectively). Educators also mark individual assignments in different disciplines (3.49). The least effective are testing (2.75 and 2.77), competitions and Olympiads (3.04 and 2.48), multimedia (3.03 and 2.88), as well as e-learning, virtual learning (3.20 and 2.88 , respectively).

\section{CONCLUSION}

The obtained theoretical and empirical results allow us to formulate the following conclusions. In general, soft skills should be considered as an innovative component of educational content in the Republic of Kazakhstan. At the same time, indicators of awareness of this phenomenon confirm the lack of systemic orientation of universities: about half of teachers and students do not yet have any ideas about soft skills. The main teaching method than by the specificity of the discipline being studied. At the same time, practical, interactive methods are more effective, rather than traditional lectures, seminars aimed mainly at mastering subject knowledge [13]. In this regard, the respondents were asked to evaluate (on a fivepoint scale: not at all effective - 1; not very effective - 2; very effective - 3 ; very effective - 4; the most effective - 5) the effectiveness of the forms and methods of teaching in which formation of soft skills ("Table 4"). 
is important to note that, as the experience of other (in particular, developing) countries shows, only state policy and reforms of the higher professional education system can lead to a large-scale introduction into curricula and programs of the necessary components for the development of soft skills [14].

\section{AUTHORS' CONTRIBUTIONS}

All the authors conceived and developed the study. Amantay Zh. A. conducted a survey, Ermakov D. S. analyzed the data obtained, and both authors jointly wrote an article. All the authors contributed to the revision of the manuscript. All authors read and approved the final manuscript and agree to be responsible for its content

\section{ACKNOWLEDGMENTS}

The publication has been prepared with the support of the "RUDN University Program 5-100".

\section{REFERENCES}

[1] Skills for social progress: the power of social and emotional skills. Paris: OECD, 2015. 140 p.

[2] Succi C., Canovi M. Soft skills to enhance graduate employability: comparing students and employers' perceptions // Studies in higher education. 2020. Vol. 45. № 9. P. 1834-1847.

[3] Cinque M. 'Lost in translation'. Soft skills development in European countries // Tuning journal. 2016. Vol. 3. № 2. P. 389-427.

[4] Ananiadou, K., \& Claro, M. (2009). 21st Century Skills and Competences for New Millennium Learners in OECD Countries. OECD Education Working Papers. No. 41. Paris: OECD Publishing. doi: $10.1787 / 218525261154$

[5] Rippard K. S. The effects cooperative grouping strategies and a three level evaluation tool on student soft skills achievement and satisfaction within a problem based instructional model in the soft sciences: dissertation ... doctor of philosophy. Norfolk, Virginia: Old Dominion University, 2014. 317 p.

[6] Survey of adult skills (PIAAC). URL: http://www.oecd.org/skills/piaac.
[7] Secondary education in Kazakhstan: state and prospects. Astana: National Academy of Education named after I. Altynsarina, 2015.248 p.

[8] Soft skills in the context of the internationalization of education: the experience of Kazakhstan // II International book collection of scientific works of young scientists, Nur-Sultan, 2020. 80-82 p.

[9] Amantay Zh. A., Ermakov, D. S. "Soft skills" model of a modern university graduate: opinions of students and teachers European Proceedings of Social and Behavioural Sciences, 2020. United Kingdom, London, Vol. 104. 30-35 p.

[10] World Economic Forum (2016). The future of jobs. Employment, skills and workforce strategy for the fourth industrial revolution: global challenge insight report. Geneva: World Economic Forum.

[11] Trilling, B., \& Fadel, C. 21st century skills: learning for life in our times. San Francisco: Jossey-Bass; John Wiley \& Sons, 2009.

[12] Loshkareva, E., Luksha, P., Ninenko, I., Smagin, I., \& Sudakov D. (2018). Skills of the future. What you need to know and be able to do in a new complex world. Moscow, Russia: Global Education Futures.

[13] Rippard K. S. The effects cooperative grouping strategies and a three level evaluation tool on student soft skills achievement and satisfaction within a problem based instructional model in the soft sciences: dissertation doctor of philosophy. Norfolk, Virginia: Old Dominion University, 2014. 317 p.

[14] Nikitina L., Furuoka F. Sharp focus on soft skills: a case study of Malaysian university students' educational expectations // Educational research for policy and practice. 2012. Vol. 11. P. 207-224. 